\title{
Reconstructing sex chromosome evolution
}

\author{
David C Page ${ }^{1 *}$, Jennifer F Hughes ${ }^{1}$, Daniel W Bellott ${ }^{1}$, Jacob L Mueller ${ }^{1}$, Mark E Gill', Amanda Larracuente ${ }^{1}$, \\ Tina Graves², Donna Muzny ${ }^{3}$, Wesley C Warren², Richard A Gibbs ${ }^{3}$, Richard K Wilson², Helen Skaletsky ${ }^{1}$ \\ From Beyond the Genome: The true gene count, human evolution and disease genomics \\ Boston, MA, USA. 11-13 October 2010
}

The mammalian $\mathrm{X}$ and $\mathrm{Y}$ chromosomes evolved from an ordinary pair of autosomes that existed in a reptilian ancestor that probably relied on temperature-dependent sex determination, as in crocodiles today. Independently and concurrently, the avian $\mathrm{Z}$ and $\mathrm{W}$ chromosomes ( $\mathrm{ZZ}$ males, ZW females) evolved from a different pair of autosomes that was present in the same ancestor. Both the mammalian $\mathrm{XY}$ pair and the avian $\mathrm{ZW}$ pair have emerged with specialized and disproportionate roles in germ cell development. These germ cell specializations are best understood in the mammalian Y chromosomes and are only now being appreciated in the mammalian $\mathrm{X}$ chromosomes and the avian ZW pair.

To reconstruct and better understand nature's sex chromosome experiment, we have set out to comprehensively sequence and compare the sex chromosomes of four primates, two rodents, an ungulate, a marsupial and a bird. I will describe insights that have emerged from this ongoing effort.

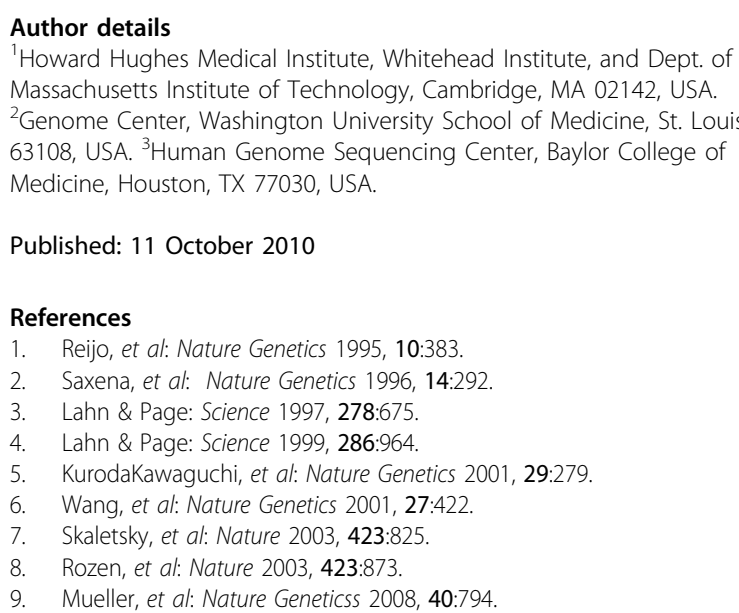

Published: 11 October 2010

'Howard Hughes Medical Institute, Whitehead Institute, and Dept. of Biology, Massachusetts Institute of Technology, Cambridge, MA 02142, USA Full list of author information is available at the end of the article
10. Lange, et al: Cell 2009, 138:855.

11. Hughes, et al: Nature 2010, 463:536.

12. Bellott, et al: Nature 2010, 466:612.

doi:10.1186/gb-2010-11-S1-121

Cite this article as: Page et al:: Reconstructing sex chromosome evolution. Genome Biology 2010 11(Suppl 1):I21.
Submit your next manuscript to BioMed Central and take full advantage of:

- Convenient online submission

- Thorough peer review

- No space constraints or color figure charges

- Immediate publication on acceptance

- Inclusion in PubMed, CAS, Scopus and Google Scholar

- Research which is freely available for redistribution

Submit your manuscript at www.biomedcentral.com/submit
C Biomed Central 